\title{
Polyol metabolism of Rhodobacter sphaeroides: biochemical characterization of a short-chain sorbitol dehydrogenase
}

\author{
Stephan Schauder, Karl-Heinz Schneider and Friedrich Giffhorn
}

Author for correspondence: Friedrich Giffhorn. Tel: +49681302 3444. Fax: +496813024360.

Lehrstuhl für Angewandte Mikrobiologie, Universität des Saarlandes, Postfach 15 11 50, D-66041 Saarbrücken, Germany

\begin{abstract}
A sorbitol dehydrogenase (SDH; L-iditol: NAD+ 2-oxidoreductase; EC 1.1.1.14) was isolated from the phototrophic bacterium Rhodobacter sphaeroides strain M22, a transposon mutant of R. sphaeroides Si4 with the transposon inserted in the mannitol dehydrogenase (MDH) gene. SDH was purified 470-fold to apparent homogeneity by ammonium sulfate precipitation, chromatography on Phenyl-Sepharose, Q-Sepharose and Matrex Gel Red-A, and by gel filtration on Superdex 200 . The relative molecular mass $\left(M_{r}\right)$ of the native SDH was 61000 as calculated from its Stokes' radius $\left(r_{3}=3.5 \mathrm{~nm}\right)$ and sedimentation coefficient $\left(S_{20, w}=4.23 S\right)$. SDS-PAGE resulted in one single band representing a polypeptide with a $M_{r}$ of 29000 , indicating that the native protein is a dimer. The isoelectric point of SDH was determined to be pH 4.8. The enzyme was specific for NAD ${ }^{+}$and catalysed the oxidation of D-glucitol (sorbitol) to Dfructose, galactitol to $D$-tagatose and of L-iditol. The apparent $K_{m}$ values were NAD+, $0.06 \mathrm{mM}$; D-glucitol, $6.2 \mathrm{mM}$; galactitol, $1.5 \mathrm{mM}$; NADH, $0.13 \mathrm{mM}$; Dfructose, $160 \mathrm{mM}$; and D-tagatose, $13 \mathrm{mM}$. The pH-optimum of substrate oxidation was 11.0 and that of substrate reduction 6-0-7.2. It was demonstrated that SDH is expressed in the wild-type strain R. sphaeroides Si4 together with MDH during growth on D-glucitol. Forty-four amino acids of the SDH $N$ terminus were sequenced. This sequence exhibited $45-55 \%$ identity to the $\mathbf{N}$-terminal sequence of 10 enzymes belonging to the short-chain alcohol dehydrogenase family.
\end{abstract}

Keywords: Rbodobacter sphaeroides, polyol metabolism, sorbitol dehydrogenase

\section{INTRODUCTION}

The phototrophic bacterium Rhodobacter sphaeroides Si4 induces a mannitol dehydrogenase (MDH) active on Dmannitol, D-glucitol (sorbitol) and D-arabitol, when grown in the presence of any of these substrates (Schneider \& Giffhorn, 1989). When grown on ribitol or xylitol it induces a ribitol dehydrogenase (RDH) active on both polyols but lacking sorbitol dehydrogenase $(\mathrm{SDH})$ activity (Kahle et al., 1992). The gene encoding MDH $(m t l K)$ has been cloned and sequenced (Schneider $e t$ al., 1993) and used for constructing a strain that overproduces the enzyme (Schneider \& Giffhorn, 1994). For cloning of $m t l K$, a transposon mutant, designated strain M22, was constructed that did not produce MDH. It was shown by sequence analysis that the transposon is inserted into $m t l K$ (Schneider et al., 1993). Unexpectedly, strain M22 still

Abbreviations: $\mathrm{MDH}$, mannitol dehydrogenase; RDH, ribitol dehydrogenase; SDH, sorbitol dehydrogenase. possesses SDH activity which has been supposed to be a marginal activity of MDH. Since it is intended to use $R$. sphaeroides Si4 as a model for experimental enzyme evolution of polyol dehydrogenases with biotechnological significance (Schneider et al., 1995), the origin of the SDH activity in the mutant M22 has to be elucidated.

This communication reports the detection, isolation and characterization of a new bacterial SDH (L-iditol : NAD ${ }^{+}$ 2-oxidoreductase; EC 1.1.1.14) from the R. sphaeroides mutant M22 and demonstrates its presence in the wildtype strain. On the basis of peptide sequence data and biochemical properties, SDH has been shown to be clearly distinct from $R$. sphaeroides Si4 MDH and RDH, but shows great similarities with enzymes of the short-chain alcohol dehydrogenase family.

\section{METHODS}

Organisms and growth conditions. The purple non-sulfur bacterium Rbodobacter sphaeroides strain Si4 (DSM 8371) is an 
isolate from this laboratory (Rode \& Giffhorn, 1983). R. sphaeroides strain M22 is a transposon mutant of strain Si4 with Tn5 inserted in the MDH gene ( $m t l K)$ (Schneider et al., 1993).

For enzyme production, cells were grown heterotrophically in a 101 bioreactor at $32^{\circ} \mathrm{C}$ with aeration $(0.3$ v.v.m.), agitation (200 r.p.m.) and $\mathrm{pH}$ regulation. The medium contained the following components in a final volume of 11 : D-glucitol, $9 \mathrm{~g}$; $\mathrm{KH}_{2} \mathrm{PO}_{4}, 1.0 \mathrm{~g} ; \mathrm{NH}_{4} \mathrm{Cl}, 1 \mathrm{~g} ; \mathrm{MgSO}_{4} .7 \mathrm{H}_{2} \mathrm{O}, 0.4 \mathrm{~g} ; \mathrm{NaCl}, 0.4 \mathrm{~g}$; $\mathrm{CaCl}_{2} .2 \mathrm{H}_{2} \mathrm{O}, 0.05 \mathrm{~g} ; 10 \times$ trace element solution SL4 (Pfennig \& Lippert, 1966), $1.0 \mathrm{ml} ; 10 \times$ vitamin solution (Rode \& Giffhorn, 1983), $1 \mathrm{ml}$. The $\mathrm{pH}$ was adjusted to $6 \cdot 8$ with $\mathrm{NaOH}$. For growth of $R$. sphaeroides M22, kanamycin was added to the medium at a concentration of $25 \mu \mathrm{g} \mathrm{ml}^{-1}$.

Enzyme assays and protein determination. Polyol dehydrogenase activities were determined as described previously (Schneider \& Giffhorn, 1989). Protein concentrations were determined by the method of Goa (1953) with crystalline bovine serum albumin as standard.

Purification of SDH. Wet cells $(78 \mathrm{~g})$ were suspended in $230 \mathrm{ml}$ Tris/ $\mathrm{HCl}$ buffer $(20 \mathrm{mM}, \mathrm{pH} 7 \cdot 0)$ and $10 \mathrm{mg}$ DNase I was added. Cells were disintegrated by two passages through a French press at $11000 \mathrm{~N} \mathrm{~cm}^{-2}$. Subsequently the cell debris was removed by centrifugation at $4{ }^{\circ} \mathrm{C}$ and $53000 \mathrm{~g}$ for $30 \mathrm{~min}$.

Unless otherwise specified all following operations were carried out at $4{ }^{\circ} \mathrm{C}$.

Step 1. During stirring on ice, saturated $\left(\mathrm{NH}_{4}\right)_{2} \mathrm{SO}_{4}$ solution was added dropwise to the crude extract until $35 \%$ saturation was reached. The precipitated proteins were removed by centrifugation at $53000 \mathrm{~g}$ for $30 \mathrm{~min}$. The supernatant was filtered through a nitrocellulose $0.45 \mu \mathrm{m}$ pore size filter.

Step 2. The protein solution from step 1 was applied to a C 16/20 Phenyl Sepharose column (Pharmacia), containing $23 \mathrm{ml}$ of the resin, equilibrated with potassium phosphate buffer $(20 \mathrm{mM}, \mathrm{pH} 7 \cdot 0)$ with $30 \%\left(\mathrm{NH}_{4}\right)_{2} \mathrm{SO}_{4}$ saturation. The proteins were eluted with a linear $\left(\mathrm{NH}_{4}\right)_{2} \mathrm{SO}_{4}$ gradient $(30-0 \%$ saturation) in $500 \mathrm{ml}$ potassium phosphate buffer $(20 \mathrm{mM}, \mathrm{pH} 7 \cdot 0)$ and $7 \mathrm{ml}$ fractions were collected. Fractions containing high $\mathrm{SDH}$ activities were pooled and dialysed against Bistris $/ \mathrm{HCl}$ buffer ( $20 \mathrm{mM}, \mathrm{pH} 6 \cdot 0)$.

Step 3. The dialysed enzyme solution was applied to a XK $50 / 30$ Q-Sepharose column with a bed volume of $80 \mathrm{ml}$, equilibrated with Bistris/ $\mathrm{HCl}$ buffer $(20 \mathrm{mM}, \mathrm{pH} 6.0)$. The enzyme was eluted with a linear $\mathrm{NaCl}$ gradient $(0-0.3 \mathrm{M})$ in $500 \mathrm{ml} \mathrm{Bistris} / \mathrm{HCl}$ buffer and $7 \mathrm{ml}$ fractions were collected. Fractions containing high enzyme activity were pooled and dialysed against Tris/ $\mathrm{HCl}$ buffer $(20 \mathrm{mM}, \mathrm{pH} 7 \cdot 5)$.

Step 4. The dialysed enzyme solution was applied to a $C 16 / 20$ Matrex Gel Red A affinity chromatography column with a bed volume of $22 \mathrm{ml}$, equilibrated with Tris $/ \mathrm{HCl}$ buffer $(20 \mathrm{mM}$, $\mathrm{pH} 7 \cdot 5)$. The enzyme was eluted with a linear $\mathrm{KCl}$ gradient $(0-0.4 \mathrm{M})$ in $400 \mathrm{ml}$ Tris $/ \mathrm{HCl}$ buffer and $5 \mathrm{ml}$ fractions were collected. Fractions containing high SDH activity were pooled and concentrated by ultrafiltration through a YM 10 membrane (Amicon) to a volume of $2 \mathrm{ml}$.

Step 5. The enzyme preparation of step 4 was further purified by FPLC gel filtration on a Superdex 200 column equilibrated with potassium phosphate buffer $(20 \mathrm{mM}, \mathrm{pH} 7 \cdot 0$, containing $0 \cdot 1 \mathrm{M} \mathrm{NaCl})$. Fractions of $2 \mathrm{ml}$ were collected at a flow rate of

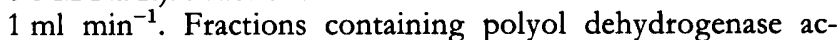
tivities were pooled and concentrated to a volume of $1 \mathrm{ml}$.

Determination of Stokes' radius and sedimentation coefficient. The Stokes' radius of the enzyme was determined using a Sephacryl S-300 column and known standards : catalase,
$5.22 \mathrm{~nm}$; aldolase, $4.81 \mathrm{~nm}$; bovine serum albumin, $3.55 \mathrm{~nm}$; ovalbumin, $3.05 \mathrm{~nm}$. The sedimentation coefficient was determined by sucrose gradient centrifugation $(6-30 \%, w / v$, sucrose) at $140000 \mathrm{~g}$ for $5 \mathrm{~h}$ with aldolase $\left(S_{20, w}=7.35 \mathrm{~S}\right)$, bovine serum albumin (4.31S) and ovalbumin (3.55S) as standards (Siegel \& Monty, 1966).

Gel electrophoresis. Analytical PAGE was carried out in $10 \%$ $(w / v)$ slab gels using the Tris-Glycine buffer system. The gels were run at a current of $20 \mathrm{~mA}$. Proteins were visualized by silver staining (Merril et al., 1981). For activity staining of the $\mathrm{SDH}$, the gels were incubated for $5 \mathrm{~min}$ in a staining solution containing the following components in a final volume of $10 \mathrm{ml}: 0 \cdot 2 \mathrm{M}$ Tris $/ \mathrm{HCl}(\mathrm{pH} 9 \cdot 0), 5 \mathrm{ml} ; 90 \mathrm{mM} \mathrm{NAD}^{+}$-solution, $100 \mu \mathrm{l}$; nitro-blue tetrazolium chloride $\left(10 \mathrm{mg} \mathrm{ml}^{-1}\right), 100 \mu \mathrm{l} ; 5-$ methylphenazonium methylsulfate $\left(1 \mathrm{mg} \mathrm{ml}^{-1}\right), 100 \mu \mathrm{l}$; Dglucitol solution $(1.5 \mathrm{M}), 1000 \mu \mathrm{l}$.

SDS-PAGE was performed in 15\% slab gels (Laemmli, 1970). The gels were run at a current of $10 \mathrm{~mA}$ per gel. For molecular mass determination of protein subunits, aldolase $\left(M_{\mathrm{r}} 39200\right)$, triose-phosphate isomerase (26000), trypsin inhibitor (20100) and lysozyme (14300) were used as standards.

Determination of the isoelectric point. Isoelectric focussing was performed in polyacrylamide gels $(5 \%)$ containing Servalyt Precotes pH 3-10 (Serva). Focussing was carried out at $400 \mathrm{~V}$ for $3 \mathrm{~h}$. The standard test mixture with proteins of known $\mathrm{pI}$

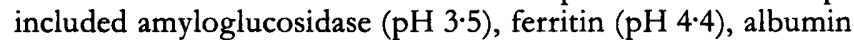
( $\mathrm{pH} 4 \cdot 7$ ), $\beta$-lactoglobulin ( $\mathrm{pH} 5 \cdot 3$ ), conalbumin ( $\mathrm{pH} 5.9$ ), horse

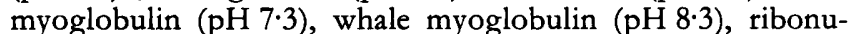
clease ( $\mathrm{pH} 9.45)$ and cytochrome $\mathrm{c}(\mathrm{pH} 10.65)$.

Determination of the reaction products. The sugars produced by oxidation of different polyols by SDH were identified with HPLC. To produce the sugars for product analysis, enzyme reactions were performed in a volume of $500 \mu \mathrm{l}$. The reaction mixture contained the following components: $100 \mathrm{mM}$ Tris/ $\mathrm{HCl}(\mathrm{pH} 8.5), 9 \mathrm{mg}$ polyol, $10 \mathrm{mg}$ sodium pyruvate, $1.4 \mu \mathrm{mol}$ $\mathrm{NAD}^{+}, 5 \mathrm{U}$ lactate dehydrogenase, and $0.22 \mathrm{U} \mathrm{SDH}$. After incubation at $28^{\circ} \mathrm{C}$ for $3 \mathrm{~h}$, the sugar produced was identified by ligand exchange chromatography with HPLC on a $\mathrm{Ca}^{2+}$-loaded cation exchange matrix (Carbohydrate $\mathrm{Ca}^{2+}, 300 \times 7 \cdot 8, \mathrm{BC}-100$, Benson). The column temperature was $85^{\circ} \mathrm{C}$. Water was used as mobile phase with a flow rate of $0.8 \mathrm{ml} \mathrm{min}$ metection was $^{-1}$. Det performed at $35^{\circ} \mathrm{C}$ with a refractive index detector (Beckman). The retention times were compared with those for authentic sugars, which were $9.5 \mathrm{~min}$ for fructose and $11.6 \mathrm{~min}$ for tagatose.

In addition $\mathrm{D}$-fructose concentration in the reaction mixture was determined by an enzymic assay (Beutler, 1984).

Chemicals and enzymes. The coenzymes, enzymes and molecular mass standards were purchased from Boehringer Mannheim. Sugars and polyols were obtained from Serva or Fluka, except L-iditol which was from Aldrich. PhenylSepharose, Q-Sepharose, Sephacryl S 300 and Superdex 200 were from Pharmacia, and Matrex Gel Red A from Amicon.

\section{RESULTS}

\section{Purification of SDH from R. sphaeroides M22}

To obtain sufficient cell material for enzyme purification R. sphaeroides M22 was grown in a 101 bioreactor on minimal medium with D-glucitol as carbon source. The growth rate was $0 \cdot 22 \mathrm{~h}^{-1}\left(t_{\mathrm{d}}=3 \cdot 15 \mathrm{~h}\right)$. Cells were harvested at the transition to stationary phase. A yield in dry mass of $1.8 \mathrm{~g} \mathrm{l}^{-1}$ was obtained. Enzyme purification 
Table 1. Purification of SDH from R. sphaeroides M22

\begin{tabular}{|c|c|c|c|c|c|}
\hline Fraction & $\begin{array}{l}\text { Total } \\
\text { activity } \\
\text { (U) }\end{array}$ & $\begin{array}{c}\text { Total } \\
\text { protein } \\
\text { (mg) }\end{array}$ & $\begin{array}{c}\text { Specific } \\
\text { activity } \\
\left(\mathrm{U} \mathrm{mg}^{-1}\right)\end{array}$ & $\begin{array}{c}\text { Purification } \\
\text { (-fold) }\end{array}$ & Yield (\%) \\
\hline Crude extract & 339 & 3685 & 0.09 & $1 \cdot 0$ & 100 \\
\hline Ammonium sulfate precipitation & 319 & 1649 & $0 \cdot 19$ & $2 \cdot 1$ & 94 \\
\hline Chromatography on Phenyl Sepharose & 216 & 203 & $1 \cdot 1$ & 12 & 64 \\
\hline Chromatography on Q-Sepharose & 113 & 17 & $6 \cdot 6$ & 73 & 33 \\
\hline Chromatography on Matrex Gel Red-A & 71 & $3 \cdot 8$ & $18 \cdot 7$ & 208 & 21 \\
\hline Gel filtration on Superdex 200 & 55 & $1 \cdot 3$ & $42 \cdot 3$ & 470 & 16 \\
\hline
\end{tabular}

was started from $78 \mathrm{~g}$ wet cells. Details of the purification procedure are described in Methods and the results are summarized in Table 1. Accordingly, SDH was purified 470 -fold to a specific activity of $42.3 \mathrm{U} \mathrm{mg}^{-1}$ with a recovery of $16 \%$.

This final enzyme preparation was apparently homogeneous as shown by analytical PAGE and SDS-PAGE, each showing one single protein band (Fig. 1a, b).

\section{Properties of SDH}

The $M_{\mathrm{r}}$ mass of the native $\mathrm{SDH}$ was calculated to be 61000 on the basis of the determined values for the Stokes' radius $\left(r_{\mathrm{s}}=3.5 \mathrm{~nm}\right)$ and the sedimentation coefficient $\left(S_{20, \mathrm{w}}=4 \cdot 23 \mathrm{~S}\right)$ (Siegel \& Monty, 1966). Since SDS-PAGE resulted in one single protein band (Fig. 1b) whose mobility corresponded to a $M_{\mathrm{r}}$ of 29000 , it was concluded that $\mathrm{SDH}$ is a dimer of identical subunits. The isoelectric point of $\mathrm{SDH}$ was determined to be $\mathrm{pH} 4.8$ by isoelectric focussing.

With respect to the coenzyme, SDH was specific for $\mathrm{NAD}^{+}$. In Table 2 the relative enzyme activities against various polyol and sugar substrates are shown. With respect to the polyols, D-glucitol is the preferred substrate of the enzyme. Lower activities could be found with Liditol and galactitol. For the reduction of sugars, Dfructose, the product of D-glucitol conversion, is the main substrate of SDH. Of the other sugars tested, only Dtagatose is converted with an activity higher than $5 \%$ of that found for D-fructose.

The reaction rates were determined in the standard assay systems at $\mathrm{pH} 9.0$ (oxidation) and $\mathrm{pH} 6.5$ (reduction). The saturation curves for all substrates tested were hyperbolic and the corresponding double-reciprocal plots were linear. The apparent $K_{\mathrm{m}}$ values determined for D-glucitol, galactitol and $\mathrm{NAD}^{+}$(in the presence of $100 \mathrm{mM}$ Dglucitol) were $6.2 \mathrm{mM}, 1.5 \mathrm{mM}$ and $0.06 \mathrm{mM}$, respectively. The $K_{m}$ values for $\mathrm{D}$-fructose, D-tagatose, and $\mathrm{NADH}$ (in the presence of $200 \mathrm{mM}$-fructose) were $160 \mathrm{mM}, 13 \mathrm{mM}$ and $0.13 \mathrm{mM}$, respectively.

The products of D-glucitol and galactitol oxidation with SDH were identified to be $\mathrm{D}$-fructose and D-tagatose, respectively, by HPLC. In addition, D-fructose was estimated by enzymic analysis (see Methods).
The optimal $\mathrm{pH}$ for substrate oxidation by SDH was $\mathrm{pH} 11.0$ as determined in $100 \mathrm{mM}$ piperazine $/ \mathrm{HCl}$ buffer. Fifty percent of this activity was found at $\mathrm{pH} 9.2$ and $50 \%$ at $\mathrm{pH} 11 \cdot 6$. Since both enzyme and NADH were not stable at the $\mathrm{pH}$ optimum, all assays monitoring substrate oxidation were performed at $\mathrm{pH} 9.0$ in $100 \mathrm{mM}$ Tris $/ \mathrm{HCl}$ buffer. Under these conditions, $48 \%$ of the maximal enzyme activity was obtained. For sugar reduction, SDH exhibited a broad $\mathrm{pH}$ optimum between $\mathrm{pH} 6.0$ and 7.2 with $50 \%$ of this activity at $\mathrm{pH} 5 \cdot 3$ and $50 \%$ at $\mathrm{pH} 7 \cdot 8$.

The stability of SDH was tested in $20 \mathrm{mM}$ potassium phosphate buffer $(\mathrm{pH} 7 \cdot 0)$ in the presence and absence of additives. When incubated at room temperature, SDH lost $50 \%$ of the initial enzyme activity after $35 \mathrm{~d}$ without the addition of additives, after $9 \mathrm{~d}$ in the presence of $1 \mathrm{mM}$ DTT, and after $140 \mathrm{~d}$ in the presence of $30 \%$ sucrose. After incubation for 3 months at $4{ }^{\circ} \mathrm{C}$ without additives as well as with $1 \mathrm{mM}$ DTT and with $30 \%$ sucrose, 95, 29 and $97 \%$ of the initial enzyme activity were found, respectively. Accordingly, SDH is stabilized by sucrose but is inactivated by DTT. Thermal stability of the enzyme was investigated in the optimal buffer potassium phosphate $(20 \mathrm{mM}, \mathrm{pH} 7.0)$ plus $30 \%$ sucrose in which the enzyme lost $50 \%$ of its initial activity during incubation at 30,40 and $50^{\circ} \mathrm{C}$ after $8 \mathrm{~d}, 18 \mathrm{~h}$ and $2 \mathrm{~min}$, respectively.

In additon to DTT, $N$-bromosuccinimide and iodoacetic acid were inhibitory on SDH. The activity of SDH was not stimulated by $\mathrm{MgSO}_{4}, \mathrm{MnSO}_{4}, \mathrm{CoCl}_{2}, \mathrm{NiCl}_{2}, \mathrm{CuSO}_{4}$ or $\mathrm{ZnSO}_{4}$, each at a concentration of $1 \mathrm{mM}$. The chelating agents EDTA and $\alpha, \alpha^{\prime}$-dipyridyl did not inhibit the enzyme at a concentration of $1 \mathrm{mM}$. These results indicate that divalent metal ions are not required for catalytic activity.

\section{Isolation of the SDH from the wild-type strain R. sphaeroides Si4}

It had been shown previously that $R$. sphaeroides Si4 expresses a $\mathrm{MDH}$ during growth on D-glucitol, Dmannitol or D-arabitol (Schneider \& Giffhorn, 1989). Since MDH oxidizes each of these polyols, it was concluded that this enzyme enables $R$. sphaeroides to utilize $\mathrm{D}$-glucitol and D-mannitol as well as D-arabitol. However, the exsistence of a SDH in the mutant strain M22 raises 
(a)

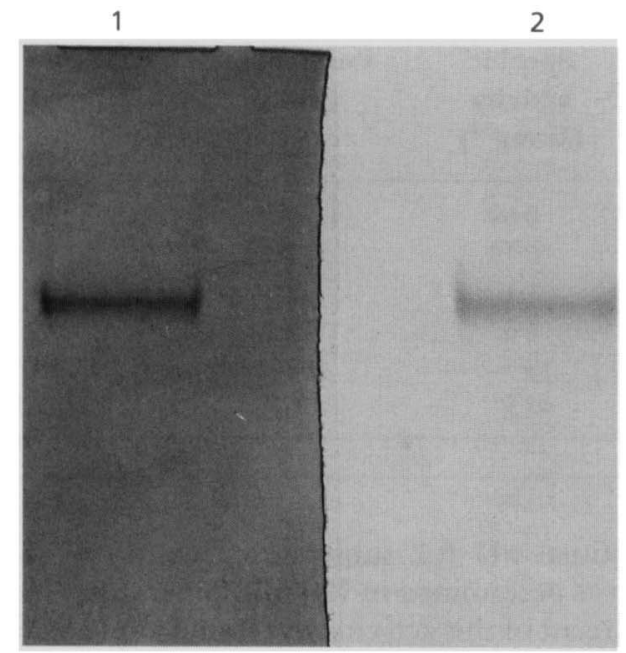

(b)

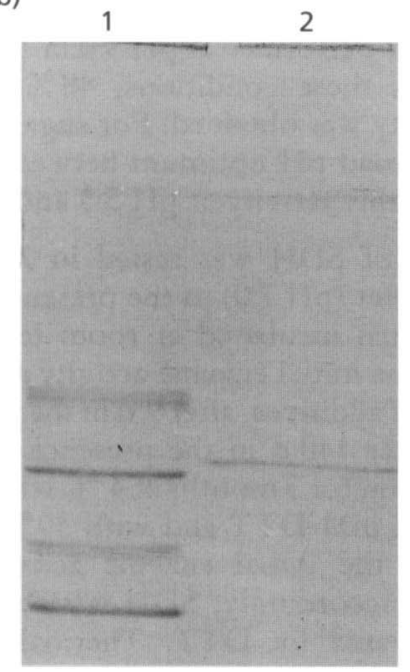

Table 2. Substrate specificity of SDH from $R$. sphaeroides

Enzyme activities in the direction of oxidation and reduction were measured in the standard assay systems at $\mathrm{pH} 9.0$ and $\mathrm{pH} 6.5$, respectively. The assays each contained $0.07 \mathrm{U}$ purified $\mathrm{SDH}$ and the substrates at saturating concentrations. These were $100 \mathrm{mM}$ for the polyols except galactitol $(20 \mathrm{mM})$, and in the reverse direction $200 \mathrm{mM}$ for all sugars except $\mathrm{D}$-xylulose $(100 \mathrm{mM})$ and lactose $(50 \mathrm{mM})$. The percentage $(100 \%$ corresponded to $0.07 \mathrm{U}$ ) values were calculated from mean values of duplicate determinations. The following compounds were not substrates for SDH: ribitol, $m$-erythritol, myo-inositol, glycerol, 1,2-pentanediol, $n$-butanol, ethanol and methanol (substrate oxidation); and L-ribulose, D-glucose, D-mannose, D-galactose, $\mathrm{D}$-arabinose, $\mathrm{L}$-arabinose, $\mathrm{D}$-xylose, D-ribose, lactose, melobiose, maltose, raffinose and $\mathrm{D}$-turanose (substrate reduction).

\begin{tabular}{|c|c|c|c|}
\hline \multicolumn{2}{|c|}{ Polyol oxidation } & \multicolumn{2}{|c|}{ Sugar reduction } \\
\hline Substrate & $\begin{array}{c}\text { Relative } \\
\text { enzyme } \\
\text { activity (\%) }\end{array}$ & Substrate & $\begin{array}{c}\text { Relative } \\
\text { enzyme } \\
\text { activity (\%) }\end{array}$ \\
\hline D-Glucitol & 100 & D-Fructose & 100 \\
\hline L-Iditol & 58 & D-Tagatose & 17 \\
\hline Galactitol & 16 & D-Xylulose & 3 \\
\hline L-Arabitol & 8 & L-Sorbose & 2 \\
\hline D-Mannitol & 4 & & \\
\hline Xylitol & 4 & & \\
\hline D-Arabitol & $<1$ & & \\
\hline
\end{tabular}

\section{Determination of the $\mathrm{N}$-terminal sequence of SDH and sequence analysis}

$\mathrm{SDH}$ was subjected to a partial amino acid sequence analysis starting from the N-terminus. Thus, 44 amino acids could be determined by automated sequencing with a 473A sequencer from Applied Biosystems. The amino acid sequence is shown in Fig. 2.

A data bank search (GenBank, EMBL Data Library, SwissProt and NBRF PIR protein database) was performed using the BLAST search algorithm. Several proteins were found that showed strong homology in their Nterminal amino acid sequence to the SDH sequence. Each of these proteins belonged to the protein family of shortchain alcohol dehydrogenases (Persson et al., 1991; Neidle et al., 1992). A sequence alignment of SDH with the 10 proteins exhibiting the highest degree of homology as well as with other polyol dehydrogenases belonging to this enzyme family is shown in Fig. 2 . No gaps had to be introduced into the amino acid sequence of any of the proteins to get a proper alignment with SDH. The 10 proteins with the highest degree of homology exhibited a $45-55 \%$ identity to SDH over the total length of 44 amino acids, and 30-39\% sequence identity was found with the polyol or polyol phosphate dehydrogenases. Therefore, SDH from R. sphaeroides is likely to be a member of the protein family of short-chain alcohol dehydrogenases, although only the $\mathrm{N}$-terminal part of the amino acid sequence is so far known. 
(a)

SDH-Rs

PGDH-Hs

ADH-Zm

AMDH-Fs

DBDDH-Pp

7HSDH-EC

BDDDH-PS

KACPR-EC

DCHDDH-Pp

3BHDH-Ct

20BHDH-Sh
MRLDGKTALITGBARGIGRAFAEAYVREGARVAIADIALEAARE

MHVNGKVALVTGAAQGIGRAFAEALLLKGAKVALVDWHLEAGVQ

(31) SHHGWDGNGAVPTPMPKRLDGXVAIVTGGARGIGEAIVRLFAKHGARVVIADIDDAAGEA TTAGVSRRPGRLAGKAAIVTGAAGGIGRATVEAYLREGASVVAMDLAPRLAAT MRLEGEVALVTGGGAGLGRA IVDRYVAEGARVAVLDKSAAGLEA

MFNSDNLRLDGRCAIITGAGAGIGKEIAITFATAGASVVVSDIHADAANH MKLKGEAVIITGGASGLGRALVDRFVAEGAKVAVLDKSAERLAE MNFEKIALVTGASRGIGRAIABTLAARGAKVIGTATSENGARI MSDLSGRTIITGGGSGIGRATVELLVASGANVPVADIXDEAGEA TNRLQGKVALVTGGASGVGLEVVKLLLGEGAKVAFSDIMEAAGQQ MNDLSGXTVITTGGARGLGAEAARQAVAAGARVVLADVLDEEGAA $++*++* *+*+*++++*+++$

(b)

SDH-Rs

ArDH-Ca

RDH-Kp

GPDH-Kp
MRLDGKTALITGBARGIGRAFAEAYVREGARVAIADIMLEAARE MDSAYWSYDNIVPSFRLDGKLVI LTGGSGGLAAVVSRALLAKGADVALVDMALERTQQ MKHSVSSMNTSLSGKVAAITEAASG IGLECARTLLGAGAKVVLIDREGEKLNK MNTWLNIKDNVI IVTGGASGIGLAIVDELLSQGAHVQMIDIHGGDRHH

Fig. 2. Alignment of the $\mathrm{N}$-terminal amino acid sequence of SDH from $R$. sphaeroides and homologous proteins identified by a database search. (a) Alignment of $R$. sphaeroides SDH and the 10 proteins exhibiting the highest degree of homology. *, Identity of an amino acid in all 10 proteins; +, identity of an amino acid in five or more proteins. The amino acid sequence of alcohol dehydrogenase from Zea mays begins at position 31 ; all other sequences start at the $\mathrm{N}$ terminus. (b) Alignment of $R$. sphaeroides SDH with other polyol or polyol phosphate dehydrogenases classified as members of the short-chain alcohol dehydrogenase family. SDH-Rs, SDH from $R$. sphaeroides (this study); PGDH-Hs, human 15-hydroxyprostaglandin dehydrogenase (Krook et al., 1990); ADH-Zm, alcohol dehydrogenase from Zea mays (Delong et al., 1993); AMDH-Fs, $\mathrm{N}$-acylmannosamine 1-dehydrogenase from Flavobacterium sp. (Yamamoto-Otake et al., 1991); DBDDH-Pp, cis-1,2-dihydrobenzene-2,2-diol dehydrogenase from Pseudomonas putida (Neidle et al., 1992); 7HSDH-Ec, 7 $\alpha$-hydroxysteroid dehydrogenase from Escherichia coli (Yoshimato et al., 1991); BDDDH-Ps, biphenyl-2,3dihydrodiol dehydrogenase from Pseudomonas sp. (Hofer et al., 1993); KACPR-Ec, ketoacyl-acyl carrier protein reductase homologue from E. coli (Verwoert et al., 1992); DCHDDH-Pp, 2,5-dichloro-2,5-cyclohexadiene-1,4-diol dehydrogenase from Pseudomonas paucimobilis (GenBank accession no. D14595); 3BHDH-Ct, $3 \beta$-hydroxysteroid dehydrogenase from Comamonas testosteroni (Yin et al., 1991); 20BHDH-Sh, 20 $\beta$-hydroxysteroid dehydrogenase from Streptomyces hydrogenans (Marekov et al., 1990); ArDH-Ca, arabinitol dehydrogenase from Candida albicans (Wong et al., 1993); RDH$\mathrm{Kp}, \mathrm{RDH}$ from Enterobacter aerogenes (Dothie et al., 1985); GPDH-Kp, D-glucitol-6-phosphate dehydrogenase from Klebsiella pneumoniae (EMBL accession no. S23835).

\section{DISCUSSION}

This and a previous study (Schneider \& Giffhorn, 1989) show that $R$. sphaeroides $\mathrm{Si} 4$ concomitantly produces $\mathrm{SDH}$ and MDH both active on D-glucitol when grown in the presence of $\mathrm{D}$-glucitol. However, the affinity of $\mathrm{SDH}$ for D-glucitol $\left(K_{\mathrm{m}}=6.2 \mathrm{mM}\right)$ and its catalytic efficiency $\left(K_{\text {cat }} / K_{\mathrm{m}}=7.0 \times 10^{3} \mathrm{M}^{-1} \mathrm{~s}^{-1}\right.$ ) are significantly higher than those of $\mathrm{MDH}\left(K_{\mathrm{m}}=32 \mathrm{mM} ; K_{\text {cat }} / K_{\mathrm{m}}=1.3 \times 10^{3}\right.$ $\left.\mathrm{M}^{-1} \mathrm{~s}^{-1}\right)$. From these data the conclusion can be drawn that both enzymes are involved in $\mathrm{R}$. sphaeroides $\mathrm{Si} 4 \mathrm{D}$ glucitol metabolism, but SDH is the predominant enzyme at low substrate concentrations. This is in agreement with the observation that both $R$. sphaeroides wild-type and the mutant strain M22 grow on D-glucitol with the same growth rate of $0.22 \mathrm{~h}^{-1}$.

From the biochemical data it is evident that $\mathrm{SDH}$ is distinct from the two other polyol dehydrogenases so far isolated from R. sphaeroides Si4 (Schneider \& Giffhorn,
1989; Kahle et al., 1992). It is also different to Bacillus subtilis SDH which is a tetrameric zinc enzyme with a $M_{\mathbf{r}}$ of $150000(\mathrm{Ng}$ et al., 1992) as well as to the most complex $\mathrm{SDH}$ of Cephalosporium chrysogenus $\left(M_{\mathrm{r}} 300000\right)$ which is composed of 10 identical subunits (Birken \& Pisano, 1976). However, the $R$. sphaeroides SDH resembles the $\mathrm{SDH}$ from Pseudomonas sp. $\left(M_{\mathrm{r}} 65000\right)$ with respect to size, subunit composition, the absence of a metal requirement and some kinetic properties (Schneider \& Giffhorn, 1991). Unlike the mammalian SDHs which generally require zinc for catalytic activity and share a high degree of structural similarity (Jeffery \& Jörnvall, 1988; Maret \& Auld, 1988; Karlsson \& Höög, 1993), microbial SDHs are much more heterogeneous. On the basis of sequence data, mammalian SDHs (Jeffery et al., 1984; Karlsson et al., 1989, 1991) have been assigned to the group of zinc-containing medium-chain alcohol dehydrogenases (Jörnvall et al., 1987). Only the SDH of B. subtilis ( $\mathrm{Ng}$ et al., 1992) and Saccharomyces cerevisiae 
(Sarthy et al., 1994) have been included in the same enzyme family and share 36 and $42 \%$ homology with the sequences of the mammalian SDHs, respectively.

However, other microbial polyol dehydrogenases have been classified on the basis of sequence data as members of the short-chain alcohol dehydrogenase family which comprises a group of relatively small enzymes exhibiting no metal requirements (Persson et al., 1991). Enzymes of this family are RDH from Enterobacter aerogenes (Dothie $e t$ al., 1985), arabinitol dehydrogenase from Candida albicans (Wong et al., 1993) and D-glucitol-6-phosphate dehydrogenase from Klebsiella pneumoniae (EMBL accession no. S23835). Although only a relatively short amino acid sequence of the $\mathrm{R}$. sphaeroides SDH is known, the comparative $\mathrm{N}$-terminal amino acid sequences of SDH and $\mathrm{MDH}$ show a significant identity between the enzymes (Schneider et al., 1995), and it will be the subject of further studies to elucidate whether SDH and $\mathrm{MDH}$ are evolutionarily related. There is also a high degree of homology between the $\mathrm{N}$-terminal parts of SDH and those of other short-chain dehydrogenases. The $\mathrm{NAD}^{+}$binding domain with the consensus sequence GXXXGXG (Wierenga et al., 1985) is located in the Nterminal part of these enzymes (Persson et al., 1991). This motif has also been found in the sequenced part of the SDH from R. sphaeroides at position 12-18 (Fig. 2). On the basis of the low molecular mass, the absence of a metal requirement and the sequence homology, we consider the SDH from R. sphaeroides Si4 to be a member of the shortchain dehydrogenase family.

\section{ACKNOWLEDGEMENTS}

We thank Dr Ralf Hoffmann, Fachrichtung Biochemie, Universität des Saarlandes, for determining the N-terminal amino acid sequence of SDH. This study was supported by grant Gi 147/2-1 of the Deutsche Forschungsgemeinschaft.

\section{REFERENCES}

Beutler, H. O. (1984). D-Sorbitol. In Methods of Enqymatic Analysis, 3rd edn, vol. VI, pp. 321-327. Edited by H. U. Bergmeyer. Weinheim: Verlag Chemie.

Birken, S. \& Pisano, M. A. (1976). Purification and properties of a polyol dehydrogenase from Cephalosporium chrysogenus. $J$ Bacteriol 125, 225-232.

Delong, A., Calderonurrea, A. \& Dellaporta, S. L. (1993). Sex determination gene TASSELSEED2 of maize encodes a shortchain alcohol dehydrogenase required for stage-specific floral organ abortion. Cell 74, 757-768.

Dothie, J. M., Giglio, J. R., Moore, C. B., Taylor, S. S. \& Hartley, B. S. (1985). Ribitol dehydrogenase of Klebsiella aerogenes. Sequence and properties of wild-type and mutant strains. Biochem $J$ 230, 569-578.

Goa, J. (1953). A micro Biuret method for protein determination. Scand J Clin Invest 5, 218-222.

Hofer, B., Eltis, L. D., Dowling, D. N. \& Timmis, K. N. (1993). Genetic analysis of a Pseudomonas locus encoding a pathway for biphenyl/polychlorinated biphenyl degradation. Gene 130, 47-55.

Jeffery, J. \& Jörnvall, H. (1988). Sorbitol dehydrogenase. Adv Enzymol Relat Areas Mol Biol 61, 47-106.
Jeffery, J., Cederlund, E. \& Jornvall, H. (1984). Sorbitol dehydrogenase. The primary structure of sheep-liver enzyme. Eur $J$ Biochem 140, 7-16.

Jornvall, H., Persson, B. \& Jeffery, J. (1987). Characteristics of alcohol/polyol dehydrogenase. Eur J Biochem 167, 195-201.

Kahle, C., Schneider, K. H. \& Giffhorn, F. (1992). Pentitol metabolism of Rbodobacter sphaeroides Si4: purification and characterization of a ribitol dehydrogenase. $J$ Gen Microbiol 138, 1277-1281.

Karlsson, C. \& Hobg, J. O. (1993). Zinc coordination in mammalian sorbitol dehydrogenase. Eur J Biochem 216, 103-107.

Karlsson, C., Maret, W., Auld, D. S., Hઠð̆g, J. O. \& Jornvall, H. (1989). Variability within mammalian sorbitol dehydrogenase. The primary structure of the human liver enzyme. Eur J Biochem 186, 543-550.

Karlsson, C., Jornvall, H. \& Hø6g, J. O. (1991). Sorbitol dehydrogenase: cDNA coding for the rat enzyme. Eur J Biochem 198, 761-765.

Krook, M., Marekov, L. \& Jornvall, H. (1990). Purification and structural characterization of placental $\mathrm{NAD}^{+}$-linked 15-hydroxyprostaglandin dehydrogenase. The primary structure reveals the enzyme belongs to the short-chain alcohol dehydrogenase family. Biochemistry 29, 738-743.

Laemmli, U. K. (1970). Cleavage of structural proteins during the assembly of the head of bacteriophage T4. Nature 227, 680-685.

Marekov, L., Krook, M. \& Jornvall, H. (1990). Prokaryotic 20קhydroxysteroid dehydrogenase is an enzyme of the 'short-chain, non-metallo-enzyme' alcohol dehydrogenase type. FEBS Lett 266, 51-54.

Maret, W. \& Auld, D. S. (1988). Purification and characterization of human liver sorbitol dehydrogenase. Biochemistry 27, 1622-1628.

Merril, C. R., Goldman, D., Sedman, S. A. \& Ebert, M. H. (1981). Ultrasensitive stain for proteins in polyacrylamide gels shows regional variations in cerebrospinal fluid proteins. Science 211, 1437-1438.

Neidle, E., Hartnett, C., Ornston, N., Bairoch, A., Rekik, M. \& Harayama, S. (1992). Cis-diol dehydrogenases encoded by the TOL pWW0 plasmid $x y l L$ gene and the Actinetobacter calcoaceticus chromosomal benD gene are members of the short-chain alcohol dehydrogenase superfamily. Eur J Biochem 204, 113-120.

Ng, K., Ye, R., Wu, X. C. \& Wong, S. L. (1992). Sorbitol dehydrogenase from Bacillus subtilis - purification, characterization and gene cloning. J Biol Chem 267, 24989-24994.

Persson, B., Krook, M. \& Jornvall, H. (1991). Characteristics of short-chain alcohol dehydrogenases and related enzymes. Eur $J$ Biocbem 200, 537-543.

Pfennig, N. \& Lippert, K. D. (1966). Über das Vitamin B 12 Bedürfnis phototropher Schwefelbakterien. Arch Microbiol 55, 245-256.

Rode, H. \& Giffhorn, F. (1983). Adaptation of Rbodopseudomonas sphaeroides to growth on $\mathrm{D}-(-)$-tartrate and large-scale production of constitutive $\mathrm{D}$-(-)-tartrate-dehydratase during growth on DLmalate. Appl Environ Microbiol 45, 716-719.

Sarthy, A. V., Schopp, C. \& Idler, K. B. (1994). Cloning and sequence determination of the gene encoding sorbitol dehydrogenase from Saccharomyces cerevisiae. Gene 140, 121-126.

Schneider, K. H. \& Giffhorn, F. (1989). Purification and properties of a polyol dehydrogenase from the phototrophic bacterium Rhodobacter sphaeroides. Eur J Biocbem 184, 15-19.

Schneider, K. H. \& Giffhorn, F. (1991). Sorbitol dehydrogenase from Pseudomonas sp.: purification, characterization and application 
to quantitative determination of sorbitol. Enzyme Microb Technol 13, 332-337.

Schneider, K. H. \& Giffhorn, F. (1994). Overproduction of mannitol dehydrogenase in Rhodobacter sphaeroides. Appl Microbiol Biotechnol 41, 578-583.

Schneider, K. H., Giffhorn, F. \& Kaplan, S. (1993). Cloning, nucleotide sequence and characterization of the mannitol dehydrogenase gene from Rhodobacter sphaeroides. J Gen Microbiol 139, 2475-2484.

Schneider, K. H., Jäkel, G., Hoffmann, R. \& Giffhorn, F. (1995). Enzyme evolution in Rhodobacter sphaeroides: selection of a mutant expressing a new galactitol dehydrogenase and biochemical characterization of the enzyme. Microbiology 141, 1865-1873.

Siegel, L. M. \& Monty, K. J. (1966). Determination of molecular weights and frictional ratios of proteins in impure systems by use of gel filtration and density gradient centrifugation. Application to crude extract preparations of sulfite and hydroxylamine reductases. Biochim Biophys Acta 112, 346-362.

Verwoert, I. I. G. S., Verbree, E. C., van der Linden, K. H., Nijkamp, H. J. J. \& Stuitje, A. R. (1992). Cloning, nucleotide sequence, and expression of the Escherichia coli fabD gene, encoding malonyl coenzyme A-acyl carrier protein transacylase. $J$ Bacteriol 174, 2851-2857.
Wierenga, R. K., DeMaeyer, M. C. H. \& Hol, W. G. J. (1985). Interaction of pyrophosphate moieties with $\alpha$-helices in dinucleotide binding proteins. Biocbemistry 24, 1346-1357.

Wong, B., Murray, J. S., Castellanos, M. \& Croen, K. D. (1993). DArabitol metabolism in Candida albicans: studies of the biosynthetic pathway and the gene that encodes NAD-dependent D-arabitol dehydrogenase. J Bacteriol 175, 6314-6320.

Yamamoto-Otake, H., Koyama, Y., Horiuchi, T. \& Nakano, E. (1991). Cloning, sequencing, and expression of the $N$-acyl-Dmannosamine dehydrogenase gene from Flavobacterium sp. strain 141-8 in Escherichia coli. Appl Environ Microbiol 57, 1418-1422

Yin, S. J., Vagelopoulos, N., Lundquist, G. \& Jörnvall, H. (1991). Pseudomonas $3 \beta$-hydroxysteroid dehydrogenase. Primary structure and relationship to the other steroid dehydrogenases. Eur J Biochem 197, 359-365.

Yoshimato, T., Hagashi, H., Kanatani, A., Lin, X. S., Nagai, H., Oyama, H., Kurazono, K. \& Tsuru, D. (1991). Cloning and sequencing of the $7 \alpha$-hydroxysteroid dehydrogenase gene from Escherichia coli HB101 and characterization of the expressed enzyme. $J$ Bacteriol 173, 2173-2179.

Received 14 December 1994; revised 7 March 1995; accepted 24 March 1995. 